\title{
A Comparison of the Staining Reactions of the Cell Walls of Azotobacter chroococcum and those of Gram-positive and Gram-negative Bacteria
}

\author{
By C. M. F. HALE and K. A. BISSET \\ Department of Bacteriology, University of Birmingham
}

SUMMARY: The effects of various reagents in the mordanting and staining of bacterial cell walls are described. The cell walls of Gram-positive bacteria were found to be much more readily stainable than those of Gram-negative organisms. In this and other respects, apart from the Gram reaction Azotobacter chroococcum resembled a Gram-positive species; some of the methods described provided an excellent illustration of its Bacillus-like morphology.

The cell walls of bacteria may be stained by the use of mordants such as tannic acid (Eisenberg, 1910) or phosphomolybdic acid (Hale, 1953) followed by basic dyes, by complexes of dyes such as the fuchsin-congo-red method of Chance (1953), and certain of the methods of Yoshida et al. (1954), and by such rather exceptional dyes as Alcian blue (Tomcsik \& Grace, 1955) which stain the cell wall directly without the intervention of a mordant. The dye-complex methods are open to the criticism of Girbardt \& Taubeneck (1955) that they do not so much stain the wall as flocculate against it. Accordingly, in the following investigation these were avoided, and the effects of a range of compounds employed as mordants upon the cell walls of a variety of bacteria were examined and compared. In addition to Alcian blue, it was also found that Janus green would stain unmordanted cell walls, and the comparison was extended to these dyes.

Since it has frequently been observed that not all bacteria react in the same manner to such staining procedures, it was considered necessary to make these tests upon a representative selection of Gram-positive and Gram-negative bacteria. And at the same time these were compared with Azotobacter, which, as has already been suggested (Bisset, 1955), although normally Gram-negative, possesses numerous characters suggestive of a relationship with the Bacillaceae.

\section{METHODS}

The bacteria examined were one strain each of Bacillus cereus and B. subtilis, Staphylococcus albus, Mycobacterium lacticola, a large coccus of Sarcina type, Aerobacter aerogenes, Escherichia coli, Proteus vulgaris, and three of Azotobacter chroococcum. All were freshly isolated in this laboratory, with the exception of Mycobacterium lacticola which was a stock culture.

The Azotobacter strains were isolated on the nitrogen-free mannitol-phosphate medium described by Bisset \& Hale (1953), on which they grew as a tough pellicle, composed of Gram-negative, almost coccal, capsulated organisms,

G. Microb. xv 
entirely typical of the genus and species. For purposes of examination, however, after purification upon a similar medium, solidified with $2 \%$ agar, they were grown upon potato-meal agar, which encourages their growth and spore formation (Bisset, 1955). Mycobacterium lacticola was grown on LowensteinJensen medium, the remainder on heart-infusion agar. Parasitic forms were incubated at $37^{\circ}$, saprophytes at $30^{\circ}$.

Smears were made, rather thickly and without the addition of water, upon no. 1 cover-glasses, and air-dried for a few seconds before being placed in the mordanting solution. After this treatment they were washed in tap water and stained, usually with a $1 \%$ aqueous solution of crystal violet, methyl green or thionin. Some of the original thick smear was washed off in the course of these procedures, leaving a thinner residue firmly adhering to the glass. When simple staining methods were used, without previous mordanting, for example with Alcian blue or Janus green, thinner smears were made in the first place. The stained preparations were mounted in water by sealing the cover-glass to a slide at the edges with melted beeswax.

In Table 1 are listed the reagents used as mordants. They were applied as $1 \%(\mathrm{w} / \mathrm{v})$ aqueous solutions in every case, and the subsequent staining was with crystal violet, which, by comparison with methyl green and thionin, was found

Table 1. The effects of various staining methods upon the cell walls of bacteria. The mordants were applied as $1 \%$ aqueous solutions, and subsequent staining was with crystal violet

\begin{tabular}{|c|c|c|c|c|c|}
\hline Mordants & $\begin{array}{c}\text { Bacillus } \\
\text { species }\end{array}$ & $\begin{array}{c}\text { Myco- } \\
\text { bacterium } \\
\text { lacticola }\end{array}$ & Cocei & $\begin{array}{c}\text { Bac- } \\
\text { teriaceae }\end{array}$ & $\begin{array}{l}\text { Azoto- } \\
\text { bacter } \\
\text { strains }\end{array}$ \\
\hline Sodium bicarbonate & - & \pm & + & - & \pm \\
\hline Sodium lactate & \pm & - & - & - & \pm \\
\hline Sodium nitrate & \pm & - & - & - & - \\
\hline Sodium chloride & - & - & \pm & - & - \\
\hline Sodium hyposulphite & - & + & + & - & - \\
\hline Potassium tellurite & - & \pm & + & - & \pm \\
\hline Potassium hydroxide & \pm & \pm & \pm & - & + \\
\hline Calcium hydroxide & + & + & + & \pm & + \\
\hline Lithium carbonate & - & \pm & + & - & - \\
\hline Ferric alum & - & - & + & - & - \\
\hline Ammonium alum & - & - & + & - & \pm \\
\hline Copper sulphate & - & - & \pm & - & \pm \\
\hline Phosphomolybdic acid & + & + & $\bar{t}$ & \pm & $\bar{t}$ \\
\hline Phosphotungstic acid & + & \pm & \pm & \pm & \pm \\
\hline Acetic acid & - & - & - & - & \pm \\
\hline Oxalic acid & - & - & - & - & \pm \\
\hline Lactic acid & - & - & - & - & \pm \\
\hline Tannic acid & + & + & + & \pm & + \\
\hline Stearic acid & - & - & \pm & $=$ & - \\
\hline Phenol & - & \pm & \pm & - & - \\
\hline Tween 80 & - & + & \pm & - & - \\
\hline \multicolumn{6}{|l|}{ Dyes } \\
\hline Alcian blue & \pm & \pm & + & \pm & + \\
\hline Janus green & + & + & + & \pm & + \\
\hline
\end{tabular}

$+=$ stains well regularly $\pm=$ stains irregularly; $-=$ fails to stain. 
to be most generally satisfactory for the purpose, although the other dyes gave better results occasionally. Mordanting and staining were both conducted at room temperature. Higher temperatures and stronger solutions were used experimentally, but these conferred no apparent advantage. Preparations were mordanted for $c .15 \mathrm{~min}$. and stained for $c .2 \mathrm{~min}$. in every case. Substances which gave uniformly negative results are not listed.

Janus green (Hopkins \& Williams) and Alcian blue (Gurr) were kept at $1 \%$ $(\mathrm{w} / \mathrm{v})$ solutions in $40 \%(\mathrm{v} / \mathrm{v})$ ethanol in water, and diluted with distilled water for use. In the case of Janus green a period of $5 \mathrm{~min}$. in a $0.01 \%$ solution produced the best results. In overstained preparations the dye diffused out into the mountant. Alcian blue was used at 0.1 \% for $15-30 \mathrm{~min}$., being a much weaker dye.

Preparations were made from $18 \mathrm{hr}$. cultures, in order to obtain active vegetative forms. However the cocci stained well at any stage of cultivation.

\section{RESULTS}

In Table 1 are shown the results of cell-wall staining, using as mordants the reagents listed in the vertical column. It can be observed that most Gramnegative bacteria stained much less well than did the Gram-positive organisms, but that the azotobacters stained exceptionally well. Some of the methods used gave an unusually good illustration of the cytological structure of Azotobacter chroococcum, and are illustrated in $\mathrm{Pl}$. 1. Calcium hydroxide not only acted as a mordant but when heated to $100^{\circ}$ it partially plasmolysed the cell contents and revealed the complexities of the structure very clearly (see Robinow, 1945, who used boiling sodium hydroxide solution). Some rods appeared as almost empty cell walls with well-marked cross-walls (Pl. 1, figs. 1, 2). Others showed differentially plasmolysed protoplasts, representing cells which had occupied a quarter, a half or the entire rod. Thus varying degrees of cellular complexity were illustrated (Pl. 1, figs. 3-6). The appearance of these plasmolysed cells and cell walls was very Bacillus-like. Potassium hydroxide produced a less marked effect, and failed to react with the Gram-negative bacteria, apart from A. chroococcum.

A second method which provided a clear illustration of the Bacillus-like characters of Azotobacter chroococcum was Janus green, which served to demonstrate not only the cell walls but also the 'cyst walls' (i.e. the spore coats) of the 'encysting' cultures. The endospore-like origin of the 'cysts', and their release by rupture of the sporangium wall were both clearly seen (Pl. 1, figs. 7, 8).

It is remarkable that although the cocci and the azotobacters were both exceptionally easy to stain, they did not react to the same compounds. For example, the three low-molecular-weight organic acids, acetic, oxalic and lactic acids, were effective only with the Azotobacter strains, of all the organisms examined. The same applied to such diverse compounds as ferric alum, stearic acid and even sodium chloride, in the case of the cocci. No explanation can be offered for these phenomena. In the cases of the metallic salts and the 
organic compounds of higher molecular weight, the reactions of the Bacillus species often differed from those of the other Gram-positive organisms, and sometimes then agreed with those of the Azotobacter strains.

\section{DISCUSSION}

Comparisons between the efficacy of different compounds as mordants gives very little help in the elucidation of the problem of what the mordanting process in bacterial cell-wall staining actually entails. The reactions observed vary very considerably, and quite unpredictably, from genus to genus, and especially as between Gram-positive and Gram-negative bacteria. The cell walls of the latter are much less easy to demonstrate. In this, as in certain morphological respects, Azotobacter chroococcum behaves like a Gram-positive organism, although normally staining Gram-negatively; some of the methods used provide an excellent illustration of the morphology of this rather curious organism.

Many previous investigations of cell-wall staining have been made upon single subjects, usually species of Bacillus (e.g. Yoshida et al. 1954), with the tacit assumption that all other bacteria react similarly, which is now seen to be quite unjustifiable. The best-known methods, using tannic or phosphomolybdic acid, have been successful precisely because their originators, including the present writers in the latter case, experimented with a variety of different bacteria, and found them all to react satisfactorily. Next best after these are probably the dyes Alcian blue and Janus green, which stain without previous mordanting.

Such little evidence as we possess about the comparative chemical constitution of bacterial cell walls suggests that Gram-positive and Gram-negative organisms are distinctly different in this respect (Salton, 1956); the anomalies recorded in this paper may be of interest to subsequent investigators in this field.

The evidence in respect of the Azotobacter strains used tends to confirm the previous observations which suggest a common ancestry for aerobic and anaerobic nitrogen-fixing bacteria (Bisset, 1955), and is in accordance with the occasional reports of early investigators that strains of this genus may be found to stain Gram-positively. The nature and behaviour of such strains will be the subject of a further communication.

\section{REFERENCES}

Bisser, K. A. (1955). Evidence from the cytology of Azotobacter chroococcum of a relationship with Rhizobium and the Bacillaceae. J. gen. Microbiol. 13, 442.

Bisset, K. A. \& Hale, C. M. F. (1953). The cytology and life-cycle of Azotobacter chroococcum. J. gen. Microbiol. 8, 442.

Chance, H. L. (1953). A bacterial cell wall stain. Stain Tech. 28, 205.

Eisenberg, P. (1910). Weitere Methoden zur Darstellung des Ektoplasmas. Z Zbl. Bakt. (Abt. 1), 53, 481.

Girbard, M. \& Taubeneck, U. (1955). Zur Frage der Zellwandfärbung bei Bakterien. Zbl. Bakt. (Abt. 1), 162, 310. 

Journal of General Microbiology, Vol. 15, No. 3

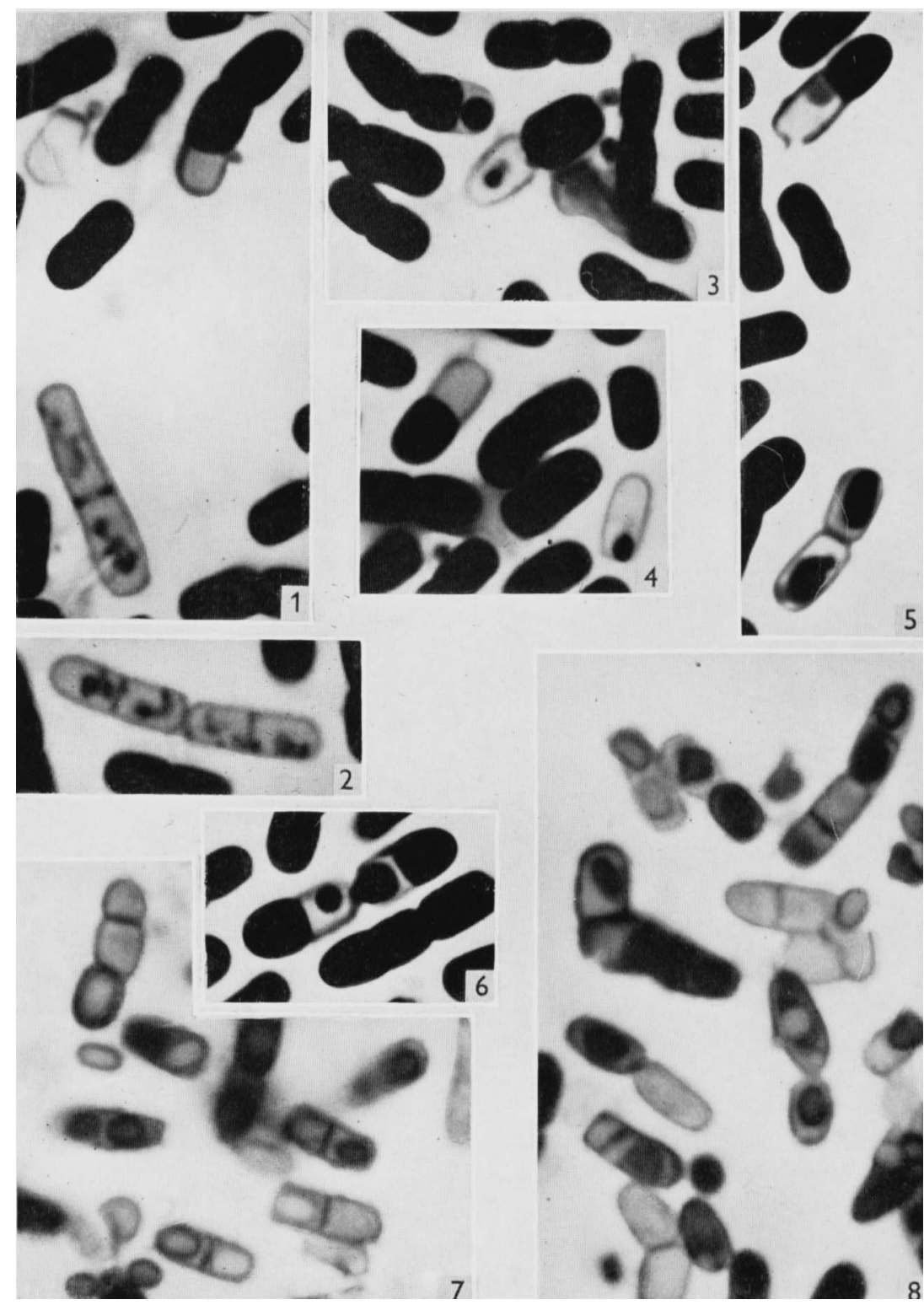

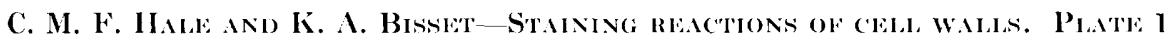
(Facing p. li27) 
Hale, C. M. F. (1953). The use of phosphomolybdic acid in the mordanting of bacterial cell walls. Lab. Practice, $2,115$.

Robrnow, C. F. (1945). Addendum to The Bacterial Cell, Dubos, R. J., Harvard University Press.

Salton, M. R. J. (1956). Bacterial cell walls. In Bacterial Anatomy, Symp. Soc. gen. Microbiol. 6, 81.

Tomcsik, J. \& Grace, J. B. (1955). Bacterial cell walls as revealed by the specific cell wall reaction and by direct staining with Alcian blue. J. gen. Microbiol. 13, 105.

Yoshida, N., Tanaka, S., Nishino, K., Fukuya, I., Takaishi, K., Kakutani, I. \& Hashrmoto, T. (1954). Studies on the bacterial cell wall. II. New techniques for staining the bacterial cell wall and septum. Tokushima J. exp. Med. 1, 153.

\section{EXPLANATION OF PLATE}

All figures are of Azotobacter chroococcum, grown on potato-meal agar. $\times 3000$.

Figs. 1-6. Young culture $(24 \mathrm{hr}$.) showing varying degrees of plasmolysis by calcium hydroxide solution. Septate filaments and bacilli containing one, two and four cells are shown.

Figs. 7-8. Sporulating culture (1 week old) stained with Janus green to show cell walls and spores; some of the latter in process of ejection.

(Received 22 March 1956) 